\title{
Population and growth of queen conch (Lobatus gigas Linnaeus, 1758) in the Sapodilla Cayes Marine Reserve of Belize
}

\author{
Isani Chan ${ }^{1}$, Li-Chun Tseng ${ }^{1}$, Hans-Uwe Dahms ${ }^{2}$ and Jiang-Shiou Hwang ${ }^{1 *}$
}

\begin{abstract}
Background: The conservation effectiveness of marine protected areas is of substantial dispute. In the Belize Barrier Reef, there are several zones with increasing human activity and harvesting of overexploited species. Marine protected areas are designed to protect endangered species and increase the population size of exploited species. The present study investigated the population and morphological characteristics of Lobatus gigas (Linnaeus, 1758) in the Sapodilla Cayes Marine Reserve (SCMR) at the southernmost tip of the Belize Barrier Reef to estimate the effectiveness of the marine protected area.

Results: A total of 693 L. gigas conches were counted over the 7,200 $\mathrm{m}^{2}$ from 36 transect lines. The densities of juveniles and adult conches in the conservation zone were substantially higher (20.13 and 2.88 individuals/100 $\mathrm{m}^{2}$, respectively) than in the general use zone (5.29 juveniles and 0.58 adults individuals/100 $\mathrm{m}^{2}$ ). The shell length of adult individuals ranged from 14.4 to $18.5 \mathrm{~cm}$ in the conservation zone and from 14.6 to $18.1 \mathrm{~cm}$ in the general use zone. A comparison of shell length of juveniles and adults showed no significant differences between the conservation zone $(11.39 \pm 1.46 \mathrm{~cm})$ and general use zone $(11.62 \pm 1.24 \mathrm{~cm})$. There was a significant positive correlation for shell length with lip thickness in the conservation zone (Pearson's correlation, $r=0.729, p<0.001$ ) and general use zone (Pearson's correlation, $r=0.613, p=0.02$ ).

Conclusions: The function and effectiveness of marine protected areas are discussed using the results of the present study that identifies the primary objective which is to ensure a continuous recruitment of valuable targeted species by the protection of spawning stock biomass that is important for the management of marine protected areas in an environmentally sensitive ecosystem.
\end{abstract}

Keywords: Queen conch; Size; Marine protected area; Conservation efficiency

\section{Background}

Overfishing has resulted in precipitous declines in many exploited populations in coastal ecosystems providing a threat to marine biodiversity (Dayton et al. 1995). As current fishery regulations appear to be inadequate to protect many exploited populations and maintain sustainable fisheries, researchers suggested that marine protected areas in which fishing is controlled and prohibited may be necessary to prevent overfishing of local species (Ballantine 1991; Bohnsack 1993; Lauck et al. 1998; Navarrete 2001). The effects of marine protected

\footnotetext{
* Correspondence: Jshwang@mail.ntou.edu.tw

${ }^{1}$ Institute of Marine Biology, College of Life Sciences, National Taiwan Ocean University, 2 Pei-Ning Road, Keelung 202, Taiwan

Full list of author information is available at the end of the article
}

areas may increase larval dispersal and influence the movements of adults from the protected area to adjacent fishing habitats as species densities build up within the zones of the marine protected areas (Polacheck 1990; Carr and Reed 1993; DeMartini 1993). Marine protected areas have been promoted as a viable complement to classical forms of fishery management (Roberts and Polunin 1991; Dugan and Davis 1993). Hence, one of the primary objectives of marine protected areas is to ensure a continuous recruitment of commercially valuable targeted species to overfished areas via protection of spawning stock biomass (Rowley 1994). The mechanisms by which spawning stock biomass complements fishing operations in the adjacent fished areas are by the export of individuals from the marine protected areas by the 
spillover effects and the production of eggs from within the reserve that contributes to the dispersal of larvae outside the reserve by enhancing the recruitment effects (Sarkis and Ward 2009).

In Central America and the Caribbean, the queen conch Lobatus gigas (Linnaeus, 1758; as synonymised Strombus gigas Linnaeus, 1758) is one of the largest gastropods (Rios-Jara et al. 2001; Wilson et al. 2005). Its geographic distribution extends from Florida and throughout the Caribbean to the northern coast of South America and Brazil (Chakalall and Cochrane 1996; Wood 1995). L. gigas are extensively fished throughout the region and are an economically valuable organism in several Central American countries (Appeldoorn 1994). During each harvesting season, millions of L. gigas are taken from the marine environment. In many regions, the population of L. gigas is fully capitalized or overfished as indicated by declining catch-per-unit efforts in local fishery records (Carcamo 2006). L. gigas has been the second largest export item in Belize next to petroleum exports (King and Petruny 2012). The extraction of L. gigas has contributed significantly to the economy of Belize. During the last decade, the annual harvest of L. gigas ranged between 181.6 and $272.5 \mathrm{t}$, being the largest export to the United States (Carcamo 2006). The Convention on International Trades in Endangered Species of Wild Fauna and Flora's (CITES) placed L. gigas in appendix 11 in 1992 because of its overexploitation (Appeldoorn 1994). Hence, one of the purposes of marine reserves in Belize was to create marine protected areas that are designed for the conservation of aquatic ecosystems, including marine wildlife and its environment including a conservation zone, preservation zone, and general use zone. The laws that govern the conservation zone and preservation zone prohibit the extraction of any marine organisms thus protecting its flora and fauna. The functions of the conservation zone prohibits the extraction of commercially valuable marine organisms but are utilized for tourism activities. The preservation zone is use for recovery of overexploited population of marine creatures, thus denies all human activities except scientific research. Therefore, the general use zone is considered as a harvested area where the commercial harvesting of marine organisms including L. gigas would be monitored and laws enforced. So far, 13 marine protected areas have been established in Belize, covering 238,761 ha or $(587,610$ acres). Among these reserves, Sapodilla Cayes Marine Reserve (SCMR) is located at the southernmost tip of the Belize Barrier Reef (Figure 1). SCMR is located in Central America; Belize has an extensive and diverse marine ecosystem ranging from fringing reefs, barrier reef, offshore atolls, and inshore patch reefs.

In Belize, L. gigas management is regulated by size restrictions. Individuals with a shell length less than $7 \mathrm{in.}$

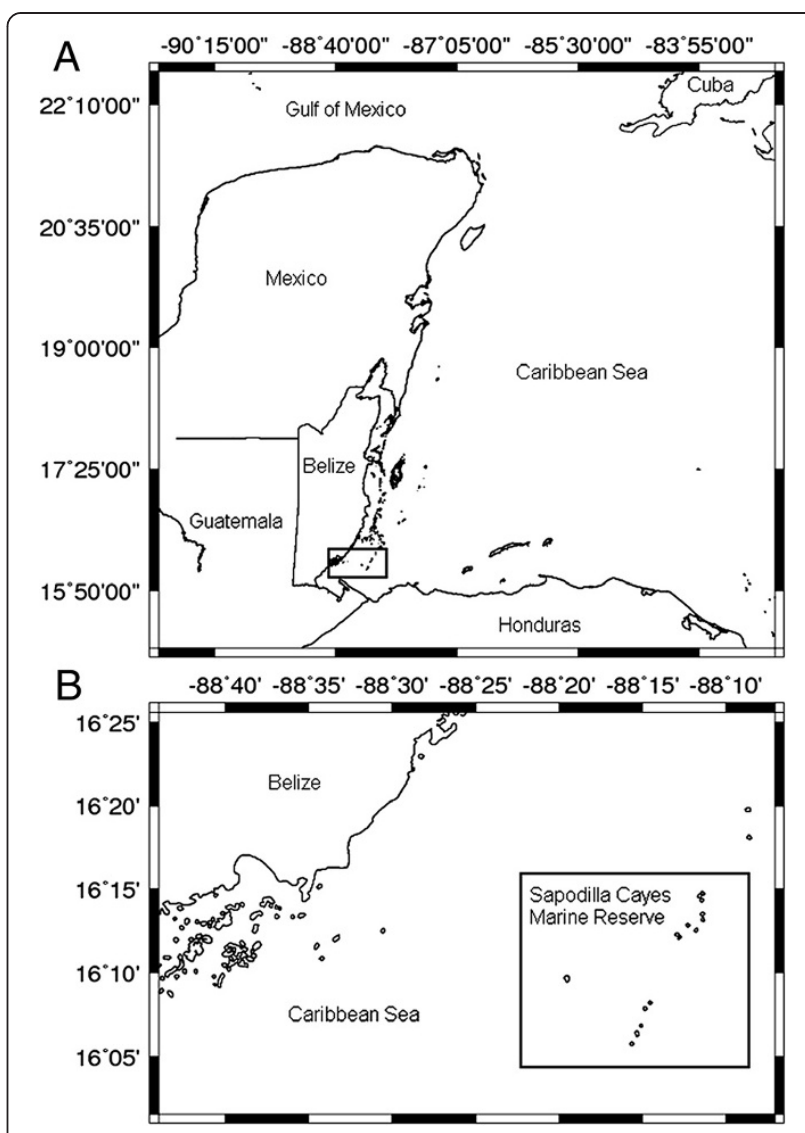

Figure 1 Map of study location of Belize (A) and the Sapodilla Cayes Marine Reserve in Belize, Central America (B).

$(178 \mathrm{~mm})$ or a weight of less than $3 \mathrm{oz}(85.049 \mathrm{~g})$ are prohibited from harvest. The morphology of L. gigas is influenced by different habitats (Appeldoorn 1994; Martín-Mora et al. 1995) and predator (Delgado et al. 2002). Several fish species make use of discarded conch shells as shelter sites (Wilson et al. 2005). Clerveaux et al. (2005) reported that the morphology of the conch shell is highly plastic.

The shell of L. gigas provides an important function for estimating sexual maturity. L. gigas shells arrest growth when individuals become mature as adults and start to expand their shell lip thickness (Valle-Esquivel 1998). The thickness of shell lips generally increase with age. Therefore, the thickness of lips can be used in assessing age and growth rate of L. gigas (Valle-Esquivel 1998). Understanding the growth rate characteristics is an essential factor that can be used for an estimate of their population dynamics (Valle-Esquivel 1998).

SCMR of Belize has been established in 1996. As yet, comprehensive biological investigations in this area are still lacking. Thus, the status of population, morphology and characteristics of L. gigas in the SCMR is still relatively unknown. In addition, reproductive biological 
data should be collected to establish morphometric relationships (Carcamo 2006, Valle-Esquivel 1998). Our objectives in the present study are aimed (1) to collect morphometric data on siphonal length and lip thickness of L. gigas, (2) to determine the correlation of morphometric data among different zones of protection, and (3) to obtain detailed information regarding population distribution of L. gigas in the SCMR.

\section{Methods}

\section{Study area}

The present study was carried out at the southernmost tip of the Belize Barrier Reef in the SCMR, which covers an area of approximately 15,619 ha $\left(125 \mathrm{~km}^{2}\right)$ and includes 14 sand and mangrove cayes. The location of the sampling areas is shown in Figure 1. The SCMR is rich in marine biodiversity since it includes various marine habitats such as mangroves and seagrass beds that provide habitat for a variety of marine organisms. The Belize Barrier Reef is the largest barrier reef in the western hemisphere. It extends for about $260 \mathrm{~km}$, from the northern border of Belize with Mexico to the southern border with Guatemala.

There are three different zones in place at the SCMR, which include the following: conservation zone, preservation zone, and general use zone. Each of these zones has different rules and regulations. The underwater environments are diverse; the substrates/habitats of seabed and their classifications are presented in three categories: dense seagrass habitats, sparse seagrass habitats, and sand flat habitats (Stoner and Waite 1990; Friedlander et al. 1994; Tewfik et al. 1998).

\section{Sampling methods and morphometric data obtained}

Individuals of $L$. gigas were retrieved by rover diving from the three different zones: conservation zone, preservation zone, and general use zone in the SCMR during August 2009. L. gigas population size was estimated using a modified belt transect method. The modified belt transect method was used to collect abundance, distribution, and morphometric data. Each transect was $50 \mathrm{~m}$ in length and $4 \mathrm{~m}$ in width and started behind the reef crest and run to an approximate depth of $15 \mathrm{~m}$, perpendicular to the shore. A total of 12 transects were laid for each investigated zone. The sites for the L. gigas survey were selected using the method of strategic site selection and stratified random sampling in the three different zones at the SCMR.

The L. gigas identified within the belt transects were counted, and their total shell siphonal length and shell lip thickness were measured by a plastic ruler and caliper; data was then recorded on a waterproof notepad. L. gigas were retransferred to the sampling area after measurements were taken. The shell length was classified as the distance from the spire tip to the anterior edge of the shell. The shell lip thickness was classified as the distance from the mid-lateral region on the lip side of the shell approximately $40 \mathrm{~mm}$ from the edge of the shell (Carcamo 2006). Therefore, based on siphonal length and shell lip thickness, L. gigas are characterized in two categories: juveniles and adults (Stoner and Waite 1990; Friedlander et al. 1994; Tewfik et al. 1998). Juveniles are identified with no shell lip or shell thickness less than $4 \mathrm{~mm}$, and adults are identified with lip thickness greater than or equal to $4 \mathrm{~mm}$ (Valle-Esquivel 1998).

\section{Hydrological structure}

The monthly averaged sea surface temperature and seawater chlorophyll $a$ values from SCMR during the sampling period of August 2009 were collected from the National Oceanic and Atmospheric Administration (NOAA) and the Sea-viewing Sensor (SeaWiFS).

\section{Date analysis}

For each zone in the SCMR, the data on shell siphonal length and shell lip thickness were analyzed to calculate the total densities of juvenile and adult identified in each zones of the marine protected area. The SPSS computer package version 13 was applied for statistical analysis. Since there was no L. gigas recorded in the preservation zone, Student's $t$ test was applied to compare differences in shell length and lip thickness between the conservation zone and general use zone. Furthermore, linear regression was used to estimate the correlation between shell lengths with lip thickness in each investigated zone.

\section{Results}

\section{Hydrological structure}

The nutrients and physical conditions usually affect the distribution and density of pollution in the marine ecosystem. The present study provided the images of chlorophyll $a$ and temperature to demonstrate the quality of food and motion of current during the sampling period. Monthly averaged information derived from the NOAA and SeaWiFS recordings for sea surface temperature and seawater chlorophyll $a$ values for the SCMR during the sampling period of August 2009 are shown in Figure 2. Located in Central America, Belize possesses a sub-tropical climate, while the temperature varies regionally; the data collected from the NOAA indicate that the average temperature was $26^{\circ} \mathrm{C}\left(78^{\circ} \mathrm{F}\right)$ at the SCMR region in the month of August 2009 (Figure 2a). Furthermore, a fluctuation of sea surface temperature was also identified along the northern border with Mexico and the southern border with Guatemala. The chlorophyll $a$ concentration within the region of the SCMR was estimated to be $0.4 \mu \mathrm{L}^{-1}$ during the month of August (Figure 2b). The levels of chlorophyll $a$ increased along the southern border 


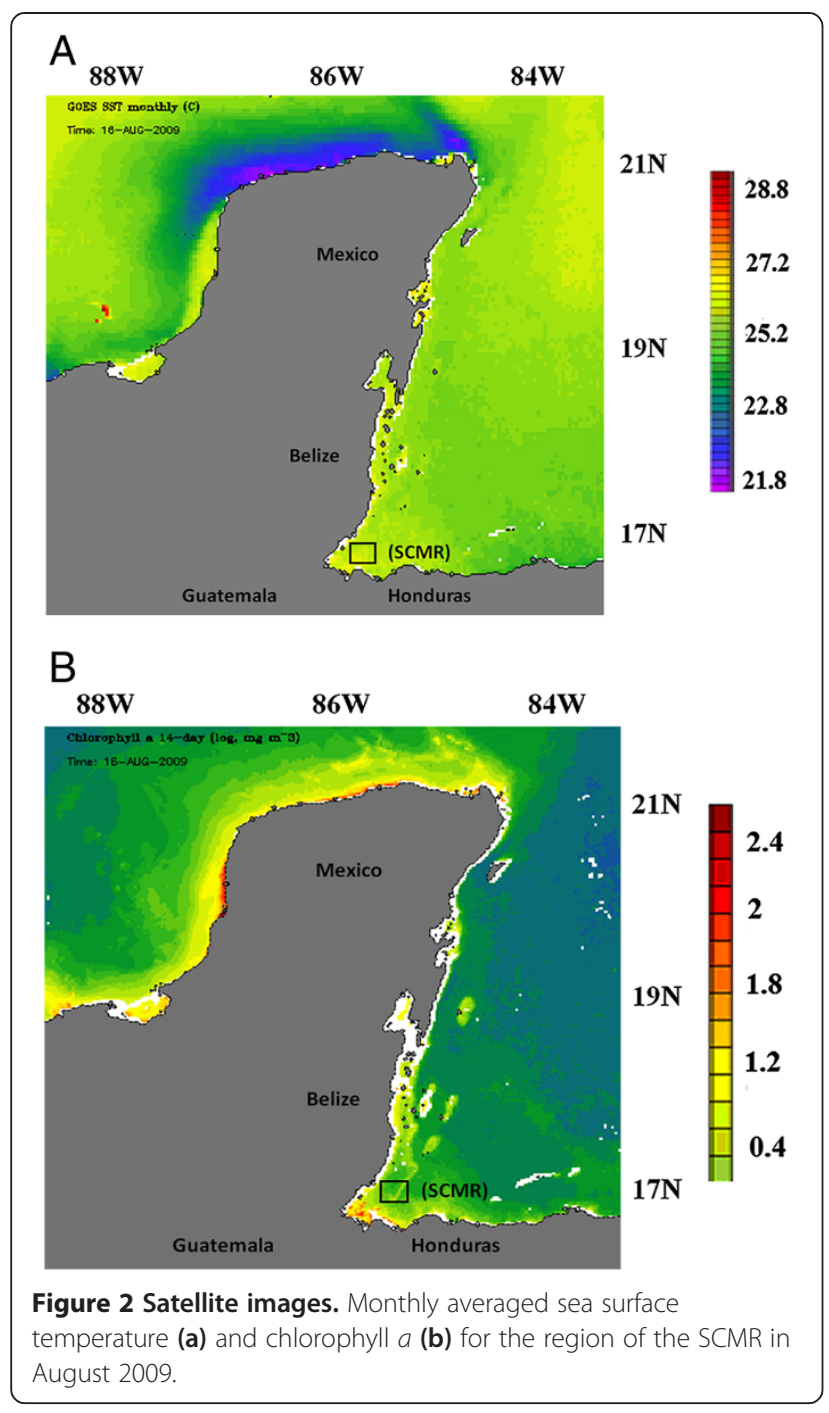

with Guatemala and decreased along the northern border with Mexico during August 2009.

\section{Population and densities of L. gigas}

A total of 693 L. gigas individuals were counted over the total surveyed 7,200 $\mathrm{m}^{2}$ area. Among the three investigated zones, 552 individuals of $L$. gigas were recorded in the conservation zone, 141 in the general use zone, and none in the preservation zone. The densities of juveniles were 20.13 individuals $/ 100 \mathrm{~m}^{2}$ (relative abundance (RA) $87.50 \%$ ) and 2.88 adult individuals/100 $\mathrm{m}^{2}$ (RA 12.50\%) in the conservation zone. The density of juveniles was 5.29 individuals $/ 100 \mathrm{~m}^{2}$ (RA $0.07 \%$ ) and adults was 0.58 individuals $/ 100 \mathrm{~m}^{2}$ (RA 9.93\%) in the general use zone (Figure 3). Legal size L. gigas with a shell length larger than $17.8 \mathrm{~cm}$ were $1.99 \%$ and $1.42 \%$ in the conservation zone and general use zone, respectively. As a result, the density of L. gigas was 3.9 times higher in the conservation zone than in the general use zone. The number of juvenile $L$.

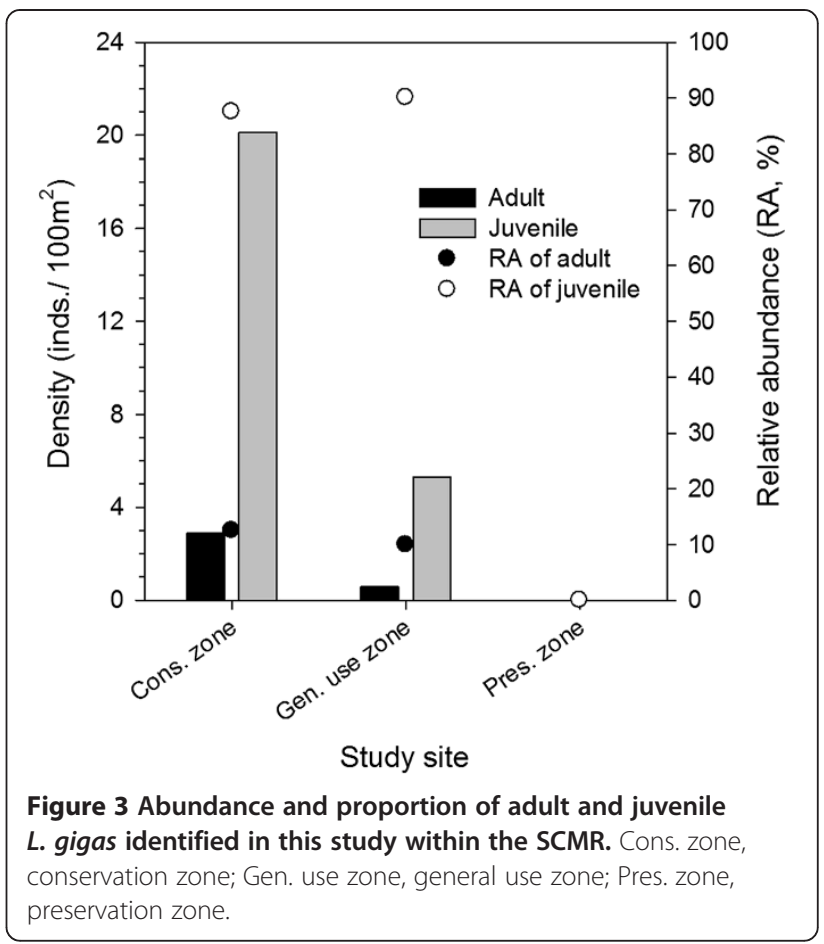

gigas was higher in both conservation zone and general use zone. Therefore, the different zones in comparison to their respective populations indicated that location has a significant effect on L. gigas density.

During the sampling period, three different habitat types of $L$. gigas were encountered throughout the investigated areas: dense seagrass habitat (DSGH), sparse seagrass habitat (SSGH), and sand flat habitat (SFH). The details of each habitat and related investigation zones are shown in Table 1. The result of distribution shows that the highest proportions (79.66\%) of L. gigas were identified from dense seagrasses and on sand flats. Thus, density seems to depend on the substrate identified in the conservation zone and in the general use zone (Figure 3 and Table 1).

\section{Characteristics of shell morphology for L. gigas}

The shell length of adult individuals ranged from 14.4 to $18.5 \mathrm{~cm}$ and from 14.6 to $18.1 \mathrm{~cm}$ for the conservation zone and general use zone, respectively (Figure 4A). The results indicated that adult individuals showed no significant differences of shell length between the conservation zone $(16.41 \pm 1.14 \mathrm{~cm})$ and general use zone $(16.32 \pm 1.21 \mathrm{~cm})$ (Student's $t$ test, $t=0.244, p=$ 0.81 ). For juvenile individuals, the length of shells ranged from 7.9 to $14.5 \mathrm{~cm}$ and from 8.7 to $14.5 \mathrm{~cm}$ for the conservation zone and general use zone (Figure 4B). A comparison of shell length of juvenile individuals indicated no significant differences between the conservation zone $(11.39 \pm 1.46 \mathrm{~cm})$ and the general use zone $(11.62 \pm 1.24 \mathrm{~cm})$ (Student's $t$ test, $t=-1.64, p=0.10)$. 
Table 1 Substrate/habitat categories used in characterizing the sites surveyed and number and proportion of identified conch

\begin{tabular}{|c|c|c|c|}
\hline Category & Description & Identified zone & Number of conch \\
\hline \multirow[t]{2}{*}{$\mathrm{DSGH}$} & \multirow[t]{2}{*}{ Coarse sand bottom dominated by seagrass Thalassia spp. and Syringodium spp. } & \multirow[t]{2}{*}{ Conservation zone } & A: $69(9.96 \%)$ \\
\hline & & & J: $483(69.7 \%)$ \\
\hline SFH & Coarse sand bottom without seagrass cover & General use zone & J: $127(18.33 \%)$ \\
\hline SSGH & Coarse sand bottom with sparse seagrass cover by Thalassia spp. and Syringodium spp. & General use zone & A: $14(2.02 \%)$ \\
\hline
\end{tabular}

A, adult individual; J, juvenile.

We correlated shell length and lip thickness for adult individuals identified in the conservation zone and general use zone. The results provided a significant positive correlation for shell length with lip thickness in both the conservation zone (linear regression, $r=0.729, p<0.001$ ) and the general use zone (linear regression, $r=0.613, p=0.02$; Figure 5). Trends of these correlations indicated that $L$. gigas found in the conservation zone have a larger shell length to lip thickness ratios than in the general use zone (Figure 5). This may be due to older age or to a better environmental situation (nutritional, less exploitation).

\section{Discussion}

The present study estimated densities of juveniles at $2,012.5$ conchs/ha and adults at 287.5 conchs/ha in the
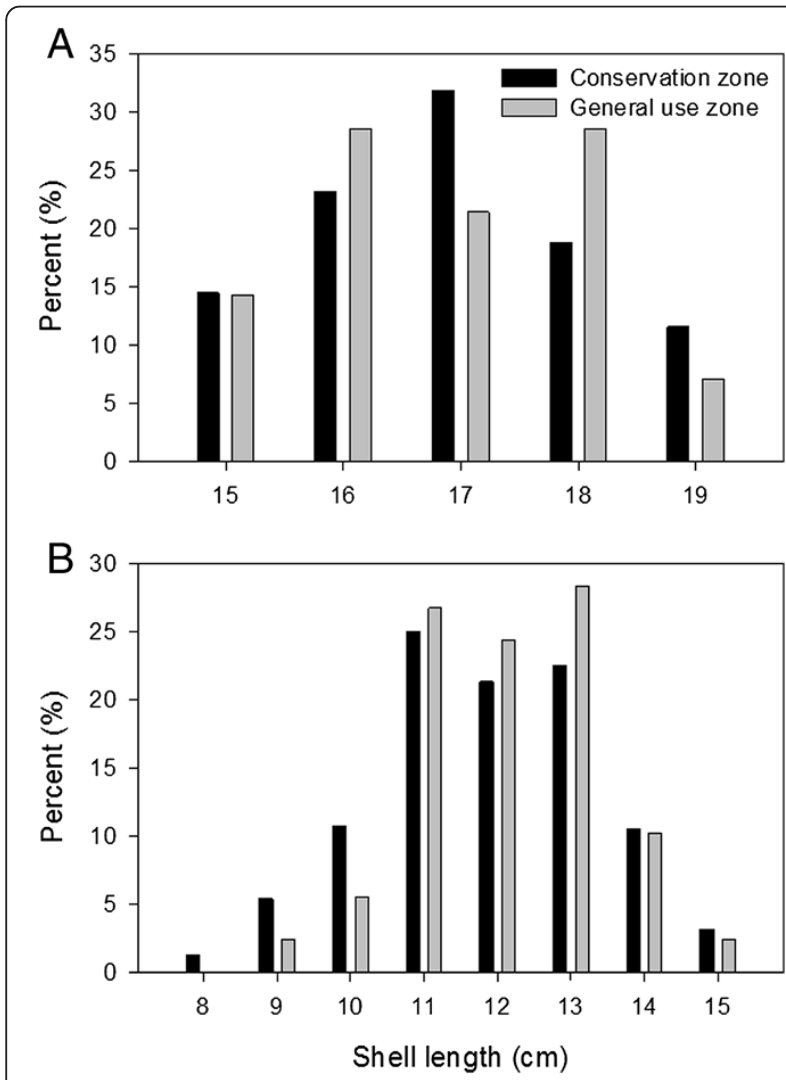

Figure 4 Length-frequency of shell for adult $(A)$ and juvenile (B) of L. gigas. conservation zone and densities of juveniles at 529.2 conchs/ha and adults at 58.3 conchs/ha in the general use zone in the SCMR during summer (season 3). Previous studies indicated that L. gigas populations vary seasonally (Stoner and Waite 1990). These authors recorded the highest density (6.73 conch/ha) occurring during the winter of 1987 (season 4) and the lowest record (0.10 conch/ ha) occurring during the fall of 1989 in Florida. These comparatively higher densities were due to aggregations of juveniles. The Caribbean Fishery Management Council (1999) recorded the highest densities of L. gigas which was $830 \mathrm{conch} / \mathrm{ha}$. Previous studies conducted in the Bahamas showed that juvenile L. gigas dominated the populations (Stoner and Sandt 1992; Caribbean Fishery Management Council 1999). Stoner and Waite (1990) reported that aggregations caused the high variances that influence the estimates of L. gigas population densities. Our results observed more than $90 \%$ juvenile individuals among L. gigas populations, confirming that the high proportion of juveniles is a common phenomenon among L. gigas in nature as in previous studies.

The present study recorded higher abundance of L. gigas in the conservation zone than in the general use zone. Previous studies reported juvenile L. gigas using exclusively shallow dense seagrass habitats as nursery

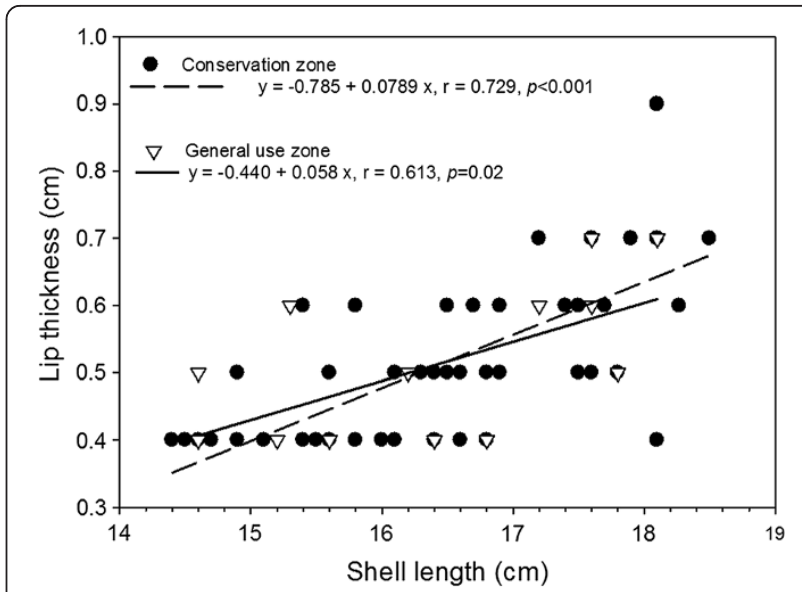

Figure $\mathbf{5}$ Lip thickness $(\mathrm{cm})$ of $L$. gigas as a function of shell length $(\mathrm{cm})$. 
grounds, as adults occupy sand flat habitats and sparse seagrass beds (Randall 1964; Alcolado 1976; Hesse 1979; Weil and Laughlin 1984; Iversen et al. 1987). L. gigas are known to use multiple essential habitats. In relation to the low abundance of adults identified in the marine reserve, this could be related to habitat selection or to the overexploitation of this species within the marine reserve (Carcamo 2006). However, illegal poaching of L. gigas is a general problem in Belize marine protected areas, as identified by fisheries officers. The association of juvenile L. gigas within dense seagrass habitats, sand flat habitats, and sparse seagrass habitats are well established (Alcolado 1976; Hesse 1979; Iversen et al. 1987; Randall 1964; Stoner and Ray 1996; Weil and Laughlin 1984). Results confirmed that juvenile L. gigas had higher abundances in dense seagrass habitat as in previous studies (Stoner and Ray 1993). Field experiments demonstrate that this resulted from habitat choice (Stoner and Waite 1990). The density of juvenile L. gigas was relatively high in dense seagrass habitats of the conservation zone, whereas the density of adult L. gigas was relatively low in this zone. In the general use zone, juvenile L. gigas density was also relatively high in the sand flat habitats and sparse seagrass habitats, and adult density was relatively low in this zone. In the preservation zone, there were no L. gigas being identified, which could be related to the habitat type (sand flat habitat, coral head, coral rubble, and gorgonian corals).

Possible factors of habitat effects have shown that the growth of juvenile L. gigas can be affected by the habitat type in which settlement of larvae is developed (Alcolado 1976; Stoner and Waite 1990; Stoner and Ray 1996). Previous studies conducted by Ray and Stoner (1995) suggested that juveniles' (2 to 5 months old) daily growth rate was higher in dense seagrass habitats than in sand flat habitats. In the present study, analyses were therefore performed that stipulate that dense seagrass habitats do provide a nursery ground for L. gigas. Thus, the habitat type in comparison of mean length and mean lip thickness does have a positive effect on $L$. gigas size and is in agreement with the aforementioned studies. Hence, the aspect of this study in comparison to the different zones clearly shows that individuals are more densely populated in the conservation zone and general use zone rather than the preservation zone. In addition, one of the most important findings of this research is that the conservation zone in the SCMR provides a better habitat for juvenile $L$. gigas inside dense seagrass beds.

This study found L. gigas individuals in the conservation zone 3.9 times more abundant than in the general use zone. As conservation work continues to be an urgent environmental need to control overfishing of marine biodiversity, marine protected areas have the potential to protect and ncrease the reproductive output of overexploited populations (Roberts and Polunin 1991; Rowley 1994). Previous studies indicated that the density and biomass of L. gigas within marine reserves result in a significantly increase population size (McField 2000; Huitric 2005). However, identifying the effects between habitat size and heterogeneity and reserve protection are important and often neglected during the process of marine protected area design (Paddack and Estes 2000). Consequently, the distribution and design of different habitat types within the marine reserve has an important role in the sustainable protection of endangered or otherwise valuable species.

The finding of Carcamo (2006) reported no significant correlation between total length and lip thickness. He suggested the fact that mature L. gigas cease their growth in relation to shell length but continue thickening their shell lips. However, previous studies clearly showed the differences of $L$. gigas shell length and lip thickness in Puerto Rico (Appeldoorn 1994), central Bahamas (Stoner and Ray 1996), and Xel-ha southeastern Mexico (ValleEsquivel 1998; Navarrete 2001; Rios-Jara et al. 2001). We also identified a significant correlation between total length and lip thickness in adult individuals. Our findings are similar to the results identified in relation to growth rate studies in Mexico (Valle-Esquivel 1998). Environmental condition can also affect shell morphology (Caldeira and Wickett 2003, 2005; Berge et al. 2006; Carcamo 2006; McCarthy 2007; Watson et al. 2009; Turley et al. 2010). Another study showed that the shell of L. gigas is characterized by high morphological plasticity (McCarthy 2007). Shell growth is also influenced by the environmental pressure of predators (Delgado et al. 2002) and habitats (Alcolado 1976).

L. gigas are preyed upon by a large variety of predators, including several species of other mollusks, crustaceans, fishes, and marine turtles. Predation pressure is particularly intense during the juvenile stages and diminishes as shell growth increases (Iversen et al. 1987). Possibly, juvenile L. gigas are consumed by upper trophic levels in the marine food web and likewise in the SCMR. This aspect needs further investigation. This study reveals high mean average lip thickness in the sparse seagrass habitat in the general use zone. The difference in growth rate may be explained by the different ecological factors and habitats being identified in various zones of the marine protected area (Stoner and Sandt 1992; Friedlander et al. 1994; Tewfik 1996). Five important factors have been identified by previous literature to influence $L$. gigas growth rate: habitat types, depth, temperature, salinity, and intra-specific competition (Friedlander et al. 1994; Tewfik 1996). Depth and temperature plays a very important role indirectly on the abundance and quality of food brought through light availability and have therefore shown to affect both density and population size within marine protected areas (Stoner and Sandt 1992; Friedlander et al. 1994; Tewfik 1996). 


\section{Conclusions}

In conclusion, the present study identified several important aspects for the management of marine protected areas. If the primary objective of marine protected areas is to ensure that fishery activities continue, the protection of environmentally sensitive areas such as spawning sites needs to be protected also considering spawning seasons. The protection of spawning sites and spawning stocks is only the first step in marine conservation, but the main goal is to maintain and likewise improve fishery yields. Therefore, marine reserves are thought to be the best tools to protect species with limited geographic dispersal. In addition, the present study provides useful information of morphological characteristics and population status of the L. gigas population in the SCMR of Belize and will be valuable for future assessments of stock and fisheries harvesting management.

\section{Competing interests}

The authors declare that they have no competing interests.

\section{Authors' contributions}

IC designed the experiment and carried out the experimental design in Belize, Central America. L-CT completed the analyzed data and creation of figures. H-UD, J-SH, and IC finalized the manuscript. All authors read and approved the final manuscript. This paper was completed during IC PhD student period in J-SH's lab, NTOU.

\section{Acknowledgements}

The authors are grateful to the manager of the Toledo Institute for Development and Environment (TIDE), Seleem Chan, for his technical support. The authors would like to acknowledge Dr. Leandra Cho-Ricketts and Dr. Edward Bold for their constructive suggestions. We thank the National Science Council of Taiwan, ROC, grant No. NSC102-2611-M-019-003 for financial support to J.-S. Hwang for partially supporting the salary to IC to complete this manuscript.

\section{Author details}

${ }^{1}$ Institute of Marine Biology, College of Life Sciences, National Taiwan Ocean University, 2 Pei-Ning Road, Keelung 202, Taiwan. ${ }^{2}$ Department of Biology, College of Natural Science, Sangmyung University, 7 Hongij-dong, Jongno-gu, Seoul 110-743, South Korea.

Received: 27 November 2012 Accepted: 13 August 2013 Published: 22 November 2013

\section{References}

Alcolado PM (1976) Growth morphological variations in the shell, and biological data of the conch ("Cobo") Strombus gigas L. (Mollusca, Mesogastropoda). Serie Oceanol Acad Cienc Cuba Inst Oceanol Habana 34:1-36

Appeldoorn RS (1994) Queen conch management and research: status, needs and priorities. In: Appeldoorn RS, Rodrı'guez Q (eds) Queen conch biology, fisheries and mariculture. Fundacio' n Científica Los Roques, Caracas, Venezuela, pp 301-319

Ballantine WJ (1991) Marine reserves the need for networks. NZJ Mar Freshwater Res 25:115-116

Berge JA, Bjerkeng B, Pettersen O, Schaanning MT, Oxnevad S (2006) Effects of increased sea water concentrations of $\mathrm{CO}_{2}$ on growth of the bivalve Mytilus edulis L. Chemosphere 62:681-687

Bohnsack JA (1993) Marine reserves: they enhance fisheries, reduce conflicts, and protect resources. Oceanus 36:63-71

Caldeira K, Wickett ME (2003) Anthropogenic carbon and ocean pH. Nature 425:365

Caldeira K, Wickett ME (2005) Ocean model predictions of chemistry changes from carbon dioxide emissions to the atmosphere and ocean. J Geophys Res 110:C09S04, 10.1029/2004JC002671
Carcamo R (2006) Stock assessment of the queen conch (Strombus gigas) population of Belize. Belize Fisheries Department Ministry of Agriculture and Fisheries, Belize City, pp 1-7

Caribbean Fishery Management Council (1999) Queen conch stock assessment and management workshop. Caribbean Fishery Management Council, Belize City

Carr MH, Reed DC (1993) Conceptual issues relevant to marine harvest refuges: examples from temperate reef fishes. J Fish Aquat 50:2019-2028

Chakalall B, Cochrane KL (1996) The queen conch fisheries in the Caribbean-an approach to responsible fisheries management. In: Posad JM, Garci M (eds) Proceeding of the first international queen conch conference. Caribbean Fisheries Management Council, San Juan, Puerto Rico, pp 60-76

Clerveaux W, Danylchuk AJ, Clerveaux V (2005) Variation in queen conch shell morphology: management implications in the Turks and Caicos Islands, BWI. Proc Gulf Caribb Fish Inst 56:715-724

Dayton PK, Thrush SF, Agardy MT (1995) Environmental effects of marine fishing. Aquat Conserv Mar Freshwater Ecosys 5:205-232

Delgado GA, Glazer RA, Stewart NJ (2002) Predator-induced behavioral and morphological plasticity in the tropical marine gastropod Strombus gigas. Biol Bull 203:112-120

DeMartini EE (1993) Modeling the potential of fishery reserves for managing Pacific coral reef fishes. Fish Bull US 91:414-427

Dugan JE, Davis GE (1993) Applications of marine harvest refugia to coastal fisheries management. J Fish Aquat 50:2029-2042

Friedlander A, Appeldoorn RS, Beets J (1994) Spatial and temporal variations in stock abundance of queen conch, Strombus gigas, in the U.S. Virgin Islands. pp. 51-60. In: Appeldoorn RS, Rodríguez B (eds) Queen conch biology, fisheries, and mariculture. Fundación Científica Los Roques, Caracas, pp 79-96

Hesse KO (1979) Movement and migration of the queen conch, Strombus gigas, in the Turks and Caicos Islands. Bull Mar Sci 29:303-311

Huitric M (2005) Lobster and conch fisheries of Belize: a history of sequential exploitation. Ecol Soc 10:21

Iversen ES, Rutherford ES, Bannerot SP, Jory DE (1987) Biological data on Berry Islands (Bahamas) queen conchs, Strombus gigas, with mariculture and fisheries management implications. Fish Bull US 85:299-310

King DT, Petruny L (2012) Belize onshore petroleum exploration activity north of the 17th parallel. Belize Petroleum Office Ministry of Natural Resources, Belmopan, pp 104-116

Lauck TC, Clark W, Mangel M, Munro GR (1998) Implementing the precautionary principle in fisheries management through marine reserves. Ecol Appl 8:S72-S78

Martín-Mora E, James FC, Stoner AW (1995) Developmental plasticity in the shell of the queen conch Strombus gigas. Ecology 76:981-994

McCarthy K (2007) A review of queen conch (Strombus gigas) life-history. In: National Marine Fisheries Service, Southeast Fisheries Science Center, Sustainable Fisheries Division Contribution to SEDAR 14 Workshop (Southeast Data, Assessment and Review), SEDAR 14-DW-4. , St. Thomas, p 8

McField MD (2000) Evaluation of management effectiveness - Belize marine protected areas system. Prepared for the CZM Authority and Institute, Belize City, p 20

Navarrete ADJ (2001) Crecimiento del caracol Strombus gigas (Gastropoda: Strombidae) en uatro ambientes de Quintana Roo, México. J Biol Trop 49:85-91

Paddack MJ, Estes JA (2000) Kelp forest fish populations in marine reserves and adjacent exploited areas of central California. Ecol Appl 10:855-870

Polacheck T (1990) Year round closed areas as a management tool. Nat Res Model 4:327-535

Randall JE (1964) Contributions to the biology of the queen conch, Strombus gigas. Bull Mar Sci Gulf Caribb 14:246-295

Ray M, Stoner AW (1995) Growth, survivorship and habitat choice in a newly settled seagrass gastropod, Strombus gigas. Mar Ecol Prog Ser 123:83-94

Rios-Jara E, Pérez-Peña M, Beas-Luna R, López-Uriarte E, Juárez-Carrillo E (2001) Gastropods and bivalves of commercial interest from the continental shelf of Jalisco and Colima, México. J Biol Trop 49:859-863

Roberts CM, Polunin NVC (1991) Are marine reserves effective in management of reef fisheries? Rev Fish Biol Fish 1:65-91

Rowley RJ (1994) Case studies and reviews, marine reserves in fisheries management. Aquat Conserv Mar Freshwater Ecosys 4:233-354

Sarkis S, Ward J (2009) Recovery plan for the queen conch, Strombus gigas, in Bermuda, Department of Conservation Services. Government of Bermuda, Flatts, p 38 
Stoner AW, Ray M (1993) Aggregation dynamics in juvenile queen conch (Strombus gigas): population structure, mortality, growth, and migration. Mar Biol 116:571-582

Stoner AW, Ray M (1996) Queen conch, Strombus gigas, in fished and unfished locations of the Bahamas: effects of a marine fishery reserve on adults, juveniles, and larval production. Fish Bull 94:551-565

Stoner AW, Sandt VJ (1992) Population structure, seasonal movements and feeding of queen conch, Strombus gigas, in deep-water habitats of the Bahamas. Bull Sci 51:287-300

Stoner AW, Waite JM (1990) Distribution and behavior of queen conch Strombus gigas relative to seagrass standing crop. Fish Bull 88:573-585

Tewfik A (1996) An assessment of the biological characteristics, abundance, and potential yield of the queen conch (Strombus gigas L.) fishery on the Pedro bank off Jamaica, M. Sc. thesis. Acadia University, Wolfville, p 139

Tewfik A, Guzman H, Hacome G (1998) Assessment of the queen conch Strombus gigas (Gastropoda: Strombidae) population in Cayos Cochinos, Honduras. Rev Biol Trop 46:137-150

Turley C, Eby M, Ridgwell AJ, Schmidt DN, Findlay HS, Brownlee C, Riebesel U, Gattuso JP, Fabry VJ, Feely RA (2010) The societal challenge of ocean acidification. Mar Poll Bull 60:787-792

Valle-Esquivel M (1998) Growth of queen conch, Strombus gigas, in Xel-Ha, Quintana Roo, Mexico. Proc Gulf Caribb Fish Inst 50:66-77

Watson SA, Southgate PC, Tyler PA, Peck LS (2009) Early larval development of the Sydney rock oyster Saccostrea glomerata under near-future predictions of $\mathrm{CO}_{2}$-driven ocean acidification. J Shellfish Res 28:431-437

Weil ME, Laughlin R (1984) Biology, population dynamics, and reproduction of the queen conch, Strombus gigas Linn, in the Archipelago de Los Roques National Park. J Shellfish Res 4:45-62

Wilson SK, Street S, Sato T (2005) Discarded queen conch (Strombus gigas) shells as shelter sites for fish. Mar Biol 147:179-188

Wood EM (1995) Study of the fishery for queen conch in Haiti. Marine Conservation Society, Ross-on Wye, p 57

doi:10.1186/1810-522X-52-46

Cite this article as: Chan et al: Population and growth of queen conch (Lobatus gigas Linnaeus, 1758) in the Sapodilla Cayes Marine Reserve of Belize. Zoological Studies 2013 52:46.

\section{Submit your manuscript to a SpringerOpen ${ }^{\circ}$ journal and benefit from:}

- Convenient online submission

- Rigorous peer review

- Immediate publication on acceptance

- Open access: articles freely available online

- High visibility within the field

- Retaining the copyright to your article

Submit your next manuscript at $\gg$ springeropen.com 